\title{
A measure of control of submerging and surfacing of an Autonomous underwater vehicle for exploring underwater of rivers
}

\author{
Le Khanh Tan ${ }^{1}$, Tran Ngoc Huy ${ }^{2, *}$, Pham Huy Hoang ${ }^{2}$
}

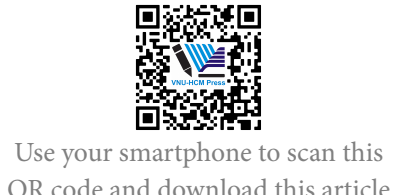

${ }^{1}$ Ho Chi Minh City University of Technology and Education (HCMUTE), Vietnam

${ }^{2}$ Ho Chi Minh City University of Technology, VNU-HCM, Vietnam

Correspondence

Tran Ngoc Huy, Ho Chi Minh City University of Technology, VNU-HCM, Vietnam

Email: tnhuy@hcmut.edu.vn

History

- Received: 13/10/2018

- Accepted: 08/01/2019

- Published: 31/12/2019

DOI : 10.32508/stdjet.v3iSI1.756

\section{Check for updates}

\section{Copyright}

(C) VNU-HCM Press. This is an openaccess article distributed under the terms of the Creative Commons Attribution 4.0 International license.

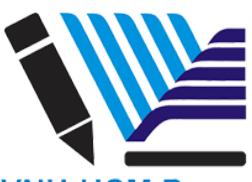

VNU-HCM Press

\section{ABSTRACT}

Autonomous underwater vehicle (AUV) known, as a special purpose underwater research vehicle (SPURV) is really a pocket submarine that could be used in multipurpose such as meteorology, probing the pollution of stream, military spying, exploring an underwater tunnel or wrecked ships and other purposes. With the reason of the power of battery inside of AUV is limited, the aim of this paper is to represent an effect way of control the submerging and surfacing of an AUV in order to save energy for a longer time service or a deeper and further expedition under water. In fact, there are so many ways for saving energy of the battery of AUV and in this paper, the selection of keeping permanently the horizontal direction of the AUV in any operation as the situation of a real submarine is applied. The diving and surfacing of AUV are consigned to the motor of the pump that consumes a little of energy to keep the proportion of the weight and the Archimedes force by pumping water inside or outside of the AUV. The selection of volume of pumped water is considered as a dynamic ballast mass for maintaining the horizontal equilibrium of the AUV at the time of submerging and surfacing. In the other hand, the controlling of the gravity point of AUV for maintaining a fixed position of gravity of the AUV when submerging and surfacing are the main factors of the paper that is also investigated in this paper. Finally, the motor of the propeller or thruster that always spends a great energy has committed only for forward or backward motion of the AUV. In this measure, the motor of thruster does not confronted with a great consummation of energy when submerging and surfacing in an oblique direction as almost all popular measures of control of AUV. ${ }^{1-9}$

Key words: Hydro metrological, AUV, ballast counterweight, propeller, diving

\section{INTRODUCTION}

In the current time, the exploration underwater in the river and the sea is in great demand for hydro metrology, military secret mission, exploration in small section water tunnel... and so many other purposes. That is an opportunity of the researchers to study, research and manufacture the Autonomous Underwater Vehicle (AUV) time by time more intelligent, more flexible and easy to control.

The AUV is able to operate in six degrees of freedom and the dynamics of an AUV are nonlinear and subjected to a variety of disturbances such as velocity of outside stream, the density and the degree of pollution of water. A kinematic and dynamic model of the AUV is derived for the six degrees of freedom operating range as in Figure 1. The degrees of freedom are limited, where only the surge, heave and yaw degrees of freedom will be controlled. Normally, a system identification approaches the direction of AUV is proposed as in Figure 2 to estimate unknown mass/inertia and damping parameters, treating the surge, heave and yaw degrees of freedom separately. The selected parameter of the AUV is based on the one that was estimated by results of experiments that have been performed through about a year in our laboratory and it is similar to a real submarine. In fact, the most common AUV shape is as a torpedo that consists of a streamlined body with propeller and control surfaces at the stern.

The purpose of this paper is to design a version of AUV that could be controlled the submerging and surfacing by pumping water in and out to take up and let out the water ballast to keep the center of gravity of the AUV fixed when submerging and surfacing.

\section{SCHEME OF DESIGN THE TYPICAL $\mathrm{AU}$}

\section{Selection of shape of UAV}

The shape of AUV must be as simple as possible. Normally it has a cylindrical body with 2 conical ends as in the Figure 1. and Technology; 2(SI1):SI151-SI156. 


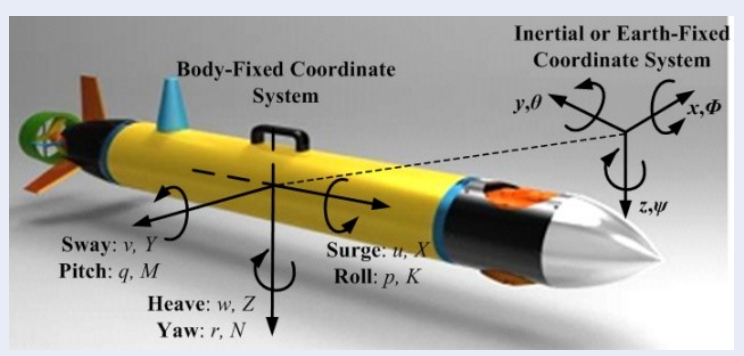

Figure 1: General shape of AUV

The proposal outside boundary dimension of the studied AUV is about $\varnothing 200 \times 1800 \mathrm{~mm}$ excluded rudder accessories. The outside diameter of UAV body is about $200 \mathrm{~mm}$.

\section{Scheme of control the center of gravity of} AUV when submerging or surfacing

There are 2 schemes of control the center of gravity of AUV:

- This version of AUV has no pumping water in and out, controls only the direction of AUV by the motion of counterweight as in Figure 2: The structure of AUV is very simple ${ }^{1}$. There is no pumping in and out water to the body of AUV so the weight of AUV is constant and slightly smaller than the Archimedes force for floating. The direction of AUV is inclining down when submerging and up when surfacing because the controlled motion of counterweight. The AUV needs to be provided a lot of energy for submerging and even when surfacing AUV because the force of propeller has to win the difference of Archimedes force and the weight of AUV. The paper does not use this type of control because of saving energy.

- Maintaining the center of AUV fixed: The proposed structure of the designed AUV is represented in Figure 3 in the scheme of fixing the center of gravity of the AUV. The direction of AUV is always slightly horizontal. To pump the outside water in and out of the AUV when submerging and surfacing saves energy of battery because in this time the propeller could be inactive for submerging and surfacing. In other to save energy from battery inside AUV, the study applies the way of submerging and surfacing as the one of a real submarine to keep the horizontal direction of AUV when submerging or surfacing.
Two similar pistons are activated by 2 similar screws and 2 similar motors to pump water by DC motors ${ }^{2}$ inside or outside of 2 rooms at the same time with the same displacement $\mathrm{x}$ in the opposite direction to keep the center of gravity of AUV stable and the direction of AUV is always horizontal. Figure 3 illustrates the distribution of weight block in the designed AUV.

\section{ARRANGEMENT OF THE OTHER INSTALLATION}

- The weight of rear and front end must be slightly equal by adjusting a fixed counterweight to keep the common center of AUV at point $\mathrm{C}$ in Figure 3.

- The propeller that is included electric motor (thruster), battery, fin and control direction as in Fiorelli $(2004)^{5}$ and Stokey $(2001)^{6}$ are located inside the rear end taper cylinder part of the AUV as in Figure 4 .

Total of instrument of the meteorology included motor, battery; camera, wave emitter and receiver are located inside the front end taper cylinder part of the AUV.

\section{COMPUTING ALL PARAMETERS OF AUV}

Outside volume of AUV:

$\mathrm{V}=2\left(\pi(100)^{2} .400 / 3\right)+\pi(100)^{2} .1000$

$=39793506.95 \mathrm{~mm}^{3}=39.7935 \mathrm{dm}^{3}$

* Archimedes' force N=39.7935x10 398 N

* With the selected total weight of AUV is $390 \mathrm{~N}$ the AUV will be on the surface of the water river because its weight is slightly smaller than Archimedes' force about $8 \mathrm{~N}$ or $0.8 \mathrm{kgfs}$. If we include $8 \mathrm{~N}$ of water inside the 2 room (with selected outside diameter of $\varnothing 200$ ), the AUV begins to dive. In order to keep the common gravity of the AUV fixed at point $\mathrm{C}$ in figure or the direction of the centerline of AUV is horizontal, the paper recommended 2 symmetrical water room where the outside water is pumped with the equal volume 


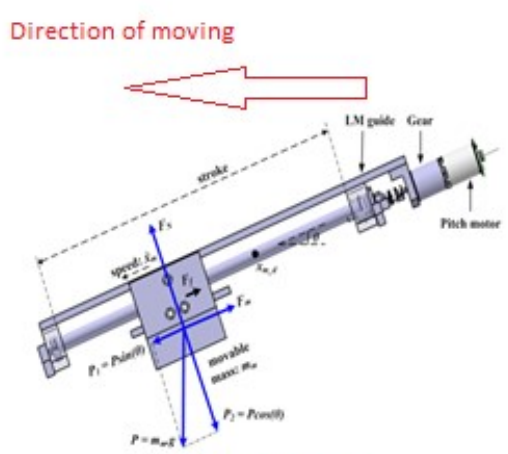

a. Submerging

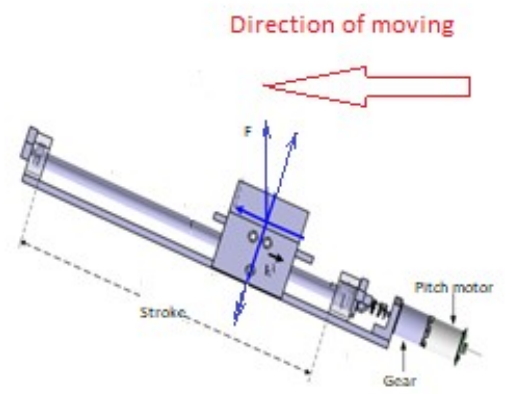

b.Surfacing

Figure 2: The position of movable mass is controlled by a pitch motor to get an oblique angle direction of AUV. The shift of mass before submerging (a) or surfacing (b) of the AUV (modified and adjusted from Ngoc-Huy T et al. $(2014)^{1}$ )

Figure 3: Schema of the distribution of weights and control the center of gravity of AUV. Herein: $c$ : The center of gravity of the whole AUV must be fixed bycontrolling the water room ballast counterweight.

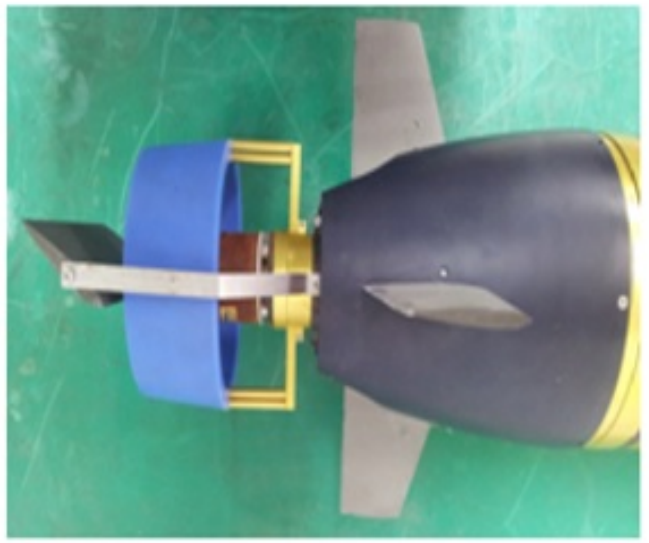

(a)

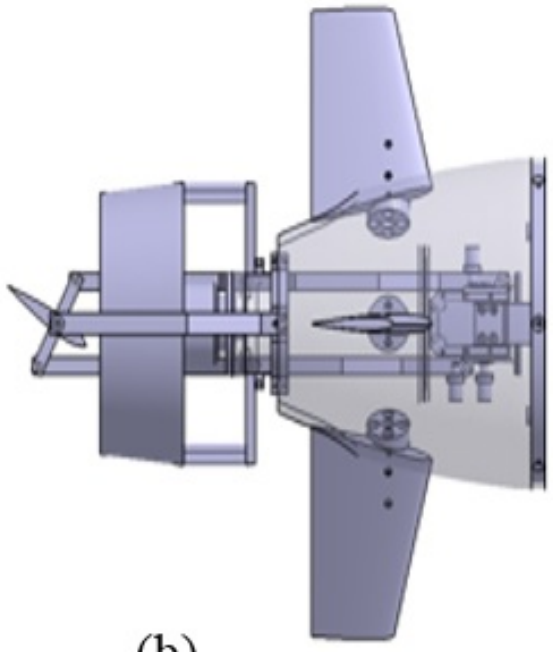

(b)

Figure 4: AUV thrust motor and propeller with protected cover and the controlling direction at rear of AUV ${ }^{1} \mathbf{a}$ : outside, $\mathbf{b}$ : inside 
into the 2 room with $4 \mathrm{~N}$ or about $0.4 \mathrm{~kg}$ of water for each room.

The minimum displacement of each piston of 2 water rooms (5 in Figure 3) is:

Minimum volume of water in each cylinder $\mathrm{v}=$ x. $\pi(90)^{2} \cdot 10^{-6} \mathrm{dm}^{3}=0.4 \Rightarrow \mathrm{x}=15.719 \mathrm{~mm}$.

Therefore, with the displacement of less than $16 \mathrm{~mm}$ the AUV had to begin dive. The reversed length according to the proposed structure in Figure 3 is about $500 \mathrm{~mm}$ for battery, motor, ball screw and the selected maximum length of water of each room is about 200 $\mathrm{mm}$.

Because the limited depth of diving of AUV is $10 \mathrm{~m}$ (the medium depth of almost all rivers in the HCM city), the outside pressure increase 1 atmosphere, a pressure sensor is installed outside of the AUV will turn off the power of 2 pumps. The pumps will active easily less than 1 absolute atmosphere to pump out the water for surfacing purpose. In fact, with the suitable adjusting of the pressure sensor the design AUV could reach at $20 \mathrm{~m}$ water depth.

- All the actuators batteries, screws, nut that are bought in the industrial market may be in appropriate material such as aluminum, copper, steel...

- Selected PVC water tubes for the outside cylinder body of the AUV that is assembled to the 2 aluminum cone rear and front ends by thread.

\section{DESIGN THE MECHANISM OF CONTROL THE POSITION OF CENTER OF GRAVITY OF AUV}

After studying on knowledge of controlling and navigating from Richard $\mathrm{B}^{7}$ and Vervoort ${ }^{8}$ we recommended an own method of the design of cruising the AUV.As mentioned above, the minimum supplementary ballast water is only $8 \mathrm{~N}$ that means that when a weight of water of $4 \mathrm{~N}$ (about $0.4 \mathrm{~kg}$ ) is pumped in each water room the AUV begins to sink. The design needs 2 similar set of pumps and cylinders and all installation have to move except the ball nut is fixed as in the Figure 5.
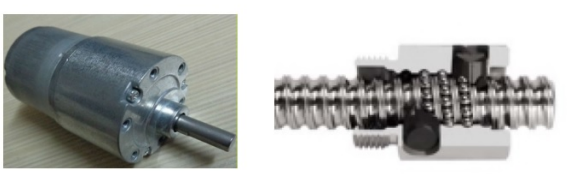

Figure 5: 2 DC Gear box electric motor and 2 SKF ball screw nut are selected to activate piston (Fixed ball nut ${ }^{3}$ and ${ }^{4}$ )
Another version of the design is using only one 2output shafts DC Gearbox motor 2 ball screws nuts with inverse helical angle that are mounted on the 2 end of the output shafts as in Figure 6. This version design of AUV saves one motor pump but also keeps the gravity center of the vehicle fixed and the horizontal direction of the AUV.

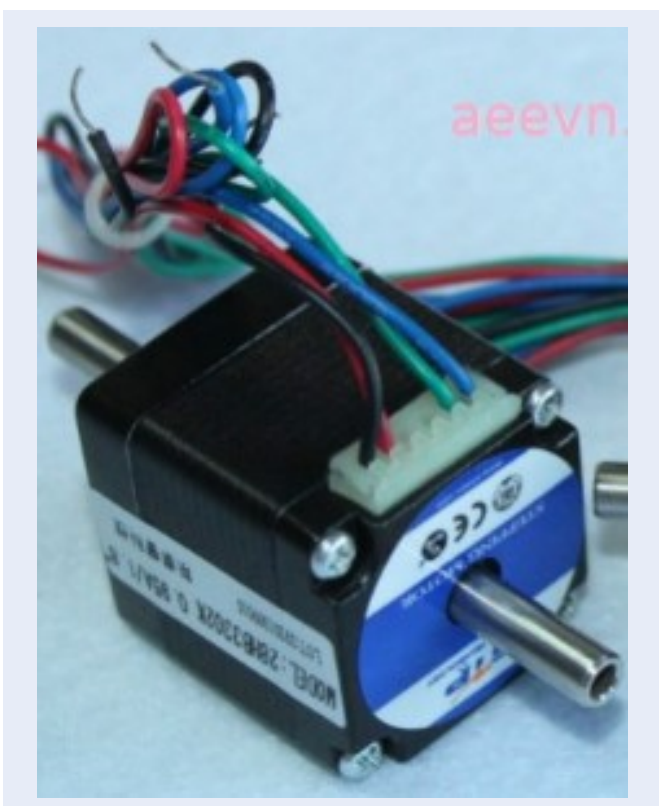

Figure 6: A 2-shafts Gear DC motor for pump ${ }^{2}$

This version of AUV is also designed to fix the center of gravity of the whole AUV but only 1 motor pump is demanded. On the sudying from Russell (2014) ${ }^{9}$ we think that on day, own AUV could be applied to the exploration underwater of canals and rivers in the city to solve the problem of protection of environment.

\section{CONCLUSION}

With the scheme of maintaining the common center, point of AUV fixed by equilibrium the water ballast, the designed AUV save lot of electric energy for the propeller from battery when submerging as well as of surfacing. The direction of AUV always keeps in the horizontal in any mission. In the other hand, the direction of the AUV is slightly horizontal as in one of real submarine that will be studied in the near future in our country

\section{ACKNOWLEDGMENTS}

This research is supported by DCSELAB and funded by Vietnam National University Ho Chi Minh City (VNU-HCM) under grant number B2018-20b-01. We appreciate highly the great support of DCSELAB 


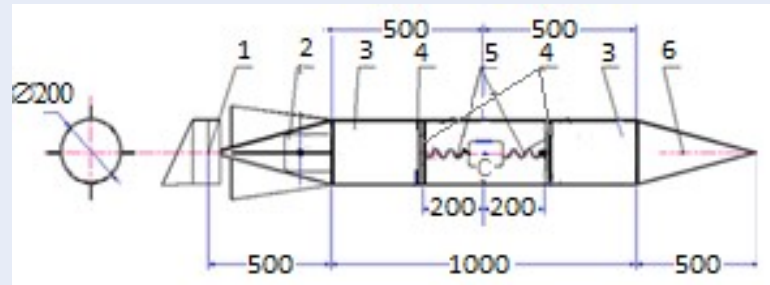

Figure 7: The structure of another version of AUV active by one motor pumps that has 2 screws at its 2 end. Herein: 1. Propeller, 2. Thruster of propeller motor and battery, 3. Symetrical ballast water rooms, 4. Hermetic symetrical pistons, 5. Two symetrical screws that activate te pistons and motors for pumping water in and out, 6 . Front room for camera and observatory instrument c: Center of gravity of the whole AUV must be fixed

which allowed and gave us a lot of facilities to perform the experiments and this paper.

\section{COMPETING INTERESTS}

This paper is our own research and we promise that there are no competition interests with any other author and paper.

\section{AUTHORS' CONTRIBUTION}

Le Khanh Tan: A measure of control diving and surfacing of AUV in the most saving energy of battery by the distribution and control the center of gravity of the AUV.

Tran Ngoc Huy: Computing of ballast counterweight to keep the horizontal direction of the AUV when operation.

Pham Huy Hoang: Abstract and checking overall the paper.

\section{REFERENCES}

1. Ngoc-Huy T, Hyeung-Sik C, Jae-Hyun B, Ji-Youn O, Jong-Rae C. Design, Control, and Implementation of New AUV Platform with a Mass Shifter Mechanism. International Journal of Precision Engineering and Manufacturing @ $\mathrm{KSPE}$ and Springer. 2014;.

2. Tsukasa Electric Company, LTD "DC gear motor";.

3. ;Available from: https://cnlongwayl.en.made-in-china.com/ \%20product/VMkmzuCdbGWa/China-15-30W-DC-GearMotor-for-Printing-Machinery.html.

4. Precision roll ball screw SKF, PUB MT/P1 06971/1 EN. 2013;

5. Fiorelli E, Leonard NE, Bhatta P, Paley D, Bachmayer R, Fratantoni DM. Multi-AUV control and adaptive sampling in Moterey Bay. Workshop on Multiple AUV Operations (AUV04). 2004;p. 134 147.

6. Stokey R, Allen B, Austin T, Goldsborough R, Forrester N, Purcell $M$, et al. Enabling technologies for REMUS docking: an integral component of an autonomous ocean-sampling network. IEEE Journal of Oceanic Engineering. 2001;26(4):487-497.

7. Blidberg DR. The Development of Autonomous Underwater Vehicles (AUV). A Brief Summary Autonomous Undersea Systems Institute, Lee New Hampshire, USA;

8. Vervoort JHAM. Modeling and Control of an Unmanned Underwater Vehicle. University of Canterbury University, Department of Mechanical Engineering Christchurch, New Zealand \& University of Technology Eindhoven, Department of Mechanical Engineering Eindhoven, The Netherlands;.

9. Wynn RB, et al. Autonomous Underwater Vehicles (AUVs): Their past, present and future contributions to the advancement of marine geoscience. Elsevier, Science Direct Marine Geology. 2014;352:451-468. 


\title{
Biện pháp điều khiển lặn và nổi thiết bị vận chuyển dưới nước không người lái
}

\author{
Lê Khánh Tân ${ }^{1}$, Trần Ngọc Huy ${ }^{2, *}$, Phạm Huy Hoàng²
}

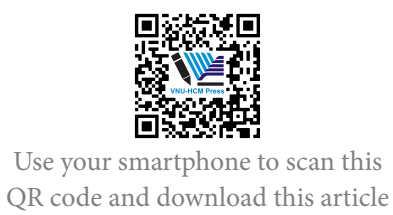

${ }^{1}$ Trường Đại học Su pham Kỹ thuật Tp. Hồ Chí Minh, Việt Nam

${ }^{2}$ Trường Đại học Bách khoa Tp. Hồ Chí Minh, Việt Nam

Liên hệ

Trần Ngọc Huy, Trường Đại học Bách khoa Tp. Hồ Chí Minh, Việt Nam

Email: tnhuy@hcmut.edu.vn

Lịch sử

- Ngày nhận: 13/10/2018

- Ngày chấp nhận: 08/01/2019

- Ngày đăng: 31/12/2019

DOI : 10.32508/stdjet.v3iSI1.756

\section{Check for updates}

\section{Bản quyền}

๑) ĐHQG Tp.HCM. Đây là bài báo công bố mở được phát hành theo các điều khoản của the Creative Commons Attribution 4.0

International license.

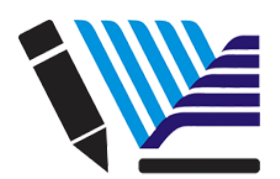

VNU-HCM Press

\section{TÓM TẮT}

Phương tiện tự động dưới nước (AUV) được gọi là phương tiện nghiên cứu dưới nước có mục đích đặc biệt (SPURV) thực sự như một tàu ngầm bỏ túi có thể được sử dụng trong đa mục đích nhu khí tượng học, thăm dò ô nhiễm dòng chảy, gián điệp quân sự, khám phá một đường hầm dưới nước hoắc tàu bị đắm và nhiều mục đích khác. Vi dung lượng của pin bên trong AUV thường bị hạn chế nên mục đích của bài viết này là giới thiệu một phương thức hiệu quả cho quá trình lặn và nổi lên của AUV nhằm tiết kiệm năng lượng của pin để có thể kéo dài thời gian hoạt động sâu hơn và xa hơn dưới nước. Trên thực tế, có rất nhiểu cách để tiết kiệm năng lượng cho pin của AUV bài viết đã lựa chọn phương thức giứ AUV luôn ở phương ngang trong mọi hoạt động như của một tàu ngầm thực sự. Việc lặn và nổi lên của AUV được giữ tỷ lệ giữa trọng lượng và lực Archimedes bằng cách bơm nước vào bên trong hoặc bên ngoài AUV dựa vào động cơ của máy bơm vốn tiêu thụ một ít năng lượng hơn là dùng chân vịt đẩy AUV xuống với phương nghiêng. Việc lựa chọn thể tích nước bơm được coi như một khối dằn động để duy trì trạng thái cân bằng ngang của AUV đồng thời việc kiểm soát trọng tâm của AUV để duy trì phương ngang của AUV khi lặn và nổi cũng như lúc di chuyển dưới sâu là những yếu tố chính được nghiên cứu trong bài báo này. Cuối cùng, động cơ của chân vịt hoặc chong chóng (luôn tiêu thụ một năng lượng lớn) chỉ được dùng cho chuyển động tiến hoặc lùi của AUV và không phải đối mặt với sức đẩu Archimede khi lặn xuống và trọng lượng của AUV khi nổi lên theo hướng nghiêng.

Từ khoá: Khí tượng thủy văn, thiết bị lặn tự hành, đối trọng, chong chóng chân vịt, lặn
Trích dẫn bài báo này: Tân $L K$, Huy $T \mathrm{~N}$, Hoàng $\mathrm{PH}$. Biện pháp điều khiển lặn và nổi thiết bị vận chuyển dưới nước không người lái. Sci. Tech. Dev. J. - Eng. Tech.; 2(SI1):SI151-SI156. 